\title{
Life and Work Health Professionals
}

Sidney Medeiros de Oliveira Vânia Barbosa do Nascimento ${ }^{2}$

\begin{abstract}
This study aims to discuss about the labor context of health professionals in Brazil, through a literature review. The idea is to draw attention to aspects that are most impacting on workers' health. The results revealed an inadequate work rate for times of rest, especially in the case of doctors and nurses. These professionals when in shifts, end up sleeping poorly and / or feeding insufficiently. Also working hard and with incompatible remuneration. These findings contrast with the need to meet social representations that populate the imagination of these professional categories. It was not intended here, to exhaust this topic or cover all health professions.
\end{abstract}

Keywords: Health professionals, life and work. employment context.

\section{Introduction}

This study aimed to contextualize health in Brazil, allowing to understand the direction that some of the inherent problems have taken, proposed solutions and conditions that have characterized the activities of some of its professionals. This is not to exhaust the topic or cover all professions relating to health, which seem to grow every day with the creation and / or recognition of new categories (eg, optometrist, radiologist). The main emphasis is on the medical profession. However, in order to understand it better, they will take into account two other categories: nurses and psychologists. The first group participates regularly in what probably represented the greatest revolution in health in recent years: the Family Health Program (PSF), and the latter has sporadic participation in such program, but with clear intention to ingrate it. It is trusted that the employment status of doctors can be made more evident when contrasted with these two professional groups.

\footnotetext{
Faculty of Medicine of ABC, São Paulo, Brazil. meolli@hotmail.com;

Faculty of Medicine of ABC, São Paulo, Brazil. vaniabn@uol.com.br.
} 
The interest in studying the health of health professionals begins initially by an understanding of how public health works in Brazil, the main sector where doctors perform their craft in this country, which occupies $69.7 \%$ of them (Carneiro \& Gouveia, 2004). This concern has been growing since it is associated with the controversy surrounding the recent changes in the world of work and current socio-economic and technological changes that play directly influence. However, the professionals interested in the subject have taken a public health concept still very focused on the epidemiological aspect (presence of diseases). In this context, the explanation of criteria and intervention in the field of medicine, for example, are still focused on the disease and not on health promotion, also understood in subjective terms, the possibilities of launching a more complex look becomes challenging .

Fortunately, according to Pouvourville (1999), the tendency to think of health in strictly biological or organic terms, as the absence of disease has been changing in recent years. So it comes to prioritizing work research in public health from a broader perspective, which includes elements of human subjectivity, admitting implications on subjective wellbeing of its promoters and users. This perspective is here admitted, thinking of health like a concrete context of professional practice, extending their evaluation to the field of subjectivity, understood as subjective well-being elements and burnout experiences. But before dealing with these aspects, it is considered the health scenario in the country, starting with the historical context that preceded it.

\section{Brief History of Health}

On this occasion, it is taken as the main reference the work of Rosen (1994). It offers a historical retrospective of health. Initially, it is stated that there has always been a concern of humanity with diseases that could be spread through contagion. Concurrently, a wider recognition has been given to the need for improvement of contextual elements that could affect health, such as physical environment, sanitation, proper and sufficient water and food, as well as a concern for the relief of disability and helplessness.

In modern age, advances related to the descriptions of diseases and their causes, as well as epidemiological studies, enabled further advancement of the state as care provider, with infection control and measures to maintain stable the health of workers. However, the 
process of industrialization and urbanization of the Industrial Revolution, which occurred in Europe in the second half of the nineteenth century, increased sanitation problems, accentuating the problems of health. The precarious living conditions generated by the agglomeration of migrant peasants in search of work, the emergence of unhealthy slums and poor hygiene worsened the incidence of infectious diseases, increasing mortality in urban centers (Rosen, 1994).

The mortality of workers hindered the operation of industries as decreased production. Thus, the government began to be pressed in order to provide preventive measures that included the improvement in sanitation and education on hygiene for the population. In this framework, social movements favored the first principles of community action in public health. This is consolidated with the Public Health Act in 1875, in England, as one of the first steps to reduce poverty and improve the living conditions of the population. The state then went on to take responsibility for the health organization and providing the necessary care for their maintenance.

Also according to Rosen (1994), by that time and by the end of the nineteenth century there were at least three paradigms about health-disease process, that continue to influence the development of public health up to this day. The first stated that the diseases were caused by emanations of animals and decaying plants (miasma current); the second took into account that the unsanitary conditions of the houses and factories were responsible for the onset of disease (social determinism); and finally, the third paradigm came from the Pasteur and Koch's discoveries about the bacteria causing various diseases, suggesting a direct relationship between the disease and the causative agent.

In the early twentieth century, medical schools in the United States and Canada have undergone an evaluation, which resulted in the preparation of the Flexner Report which had a major impact, causing the closure of nearly two-thirds of medical schools of the time. This proposed strict measures aiming to improve the quality of medical services (Paim \& Almeida Filho, 1998; Silva Jr., 1998).

According to Mendes (1995), following the paradigm of the bacteriologist current, the Brazilian public health was strengthened with the creation of the Federal Serum Therapy Institute in 1900 with the intention to manufacture vaccines and serums. This author says that despite the government trying to maintain a healthy workforce and free of contamination 
inputs, it also blamed the population for the health problems, requiring compliance with hygiene habits.

Rosen (1994) suggests that starting from 1930, with the worsening of living conditions in the cities, the growth of proletarian social movements starts to influence the emergence of new forms of health care to the population. Mass vaccination and health campaigns begin to take place to control epidemics, as well as iniciated the provision of basic health services in health centers in the suburbs.

Over time, these measures were no longer meeting the needs of the population, and in the 1960s, the working class has already started a fight for better health. By 1970, the country goes through various political, social and economic changes, which influenced significantly the health policies of the time. A scenario of internal and disorderly migration, population growth and expansion of large urban centers, allied with interest rise stemming from the high external debt of the country aggravate the economic situation with high inflation and recession.

In the above mentioned interval, Rosen (1994) suggests, the Sanitary Movement takes place, consolidated in mid 1960. This was formed basically by progressive intellectuals and popular movements that criticized the health care model in force at the time, calling for an attention to free health and accessible to the entire population, not only the working class. According to Damaso (1995), this movement sought through legal and administrative arrangements, emphasizing the link between health, disease and society. In another context, also sought-expand public awareness of the right to health, as well as strengthen the public service quality, accessible to all and also expand the public awareness to the aspect of the need for public hygiene.

According to Mendes (1995, p.2), the care model of the time favored "curative medical practice, and individual welfare at the expense of public health", being "oriented in terms of profitability of the health sector providing the capitalization of medicine." This model constitutes as highly elitist, favoring the private producer of health services. And because Brazil was experiencing a social time marked by inequalities in access to goods and services it did not meet the social demands, especially from the less privileged classes and rural areas.

In this context, being the current medical practice the healing, it was not able to change the population morbidity and mortality rates, denouncing the failure of this care 
model. Also, there were no criteria in the exchange between the State towards private services available, generating evident dissatisfaction of users, health professionals and providers of these services. Therefore, new proposals for change was demanded on health care in Brazil.

Fraud, waste of resources, low quality scores in assistances made urgent reformulation of current health care form. In this direction, in 1979 the Ministry of Health and Welfare creates PREVSAUDE, an assistance plan that standardized health procedures, the form of assistance, tiering professional services, reducing and providing a control in private sector activities and allowing community participation in decisions on prioritization of measures of health actions.

This new order in health care stimulated in 1981, the creation of CONASP (Consultative Council of the Social Security Health Administration) and the Reorientation Plan of Health Care in the scope of Social Security, aimed at improving the quality of care, a more humanized care and more accessible to the population at all levels. The Council gave priority to basic health care, outpatient care, the use of spare capacity in the public sector, minimizing the purchase of private services and the decentralization of the health care network and unification of procedures and criteria.

From 1983, still following the the planning of CONASP, the Program Hospital Accounts Rationalization, with the introduction of Hospitalization Authorization (AIH) was established, and also the Program of Integrated Health Actions (AIS), which have guided the organization of health actions the population in a more structured and coordinated manner. This action aimed at improving the system through healthcare improvement, health professional development, offering pay and better working conditions, hiring multidisciplinary teams of professionals such as social workers, psychologists, occupational therapists, nutritionists, among others.

The Eighth National Health Conference in 1986 had a priority focus on the discussion of the bases of Brazilian health reform bill through the expansion of the range of health professionals and the establishment of a National Health System to meet the principle of health as a right to citizenship and duty of the State. According to Carvalho (1995), the conference was an unprecedented event in the history of health policies, since civil society had never been called to discuss the government policies related to health. Maybe that's why there has been a low participation of these characters in the discussions, which consisted almost entirely of government experts and health managers. 
Luz (1994) notes that the major differences in relation to concepts discussed in the previous conferences was that for the first time, health is no longer conceived as a purely biological state of absence of diseases and began to be perceived as an arising state of a set of biopsycho-social conditions, overcoming the current medicalized conception. The decentralization of health services involved in the transfer of responsibilities to states and municipalities, also considering the claims and evaluation of the population, avoiding the centralization of decisions, which are confided to, would speed up healthcare processes and procedures.

In 1987 he implemented the SUDS (Unified System and Decentralized Health), a way to improve the Health Integrated Action Program, and in 1988 was approved, in the new Brazilian Constitution, the Unified Health System (SUS), based on a proposal to regulate care services to the population health. This system is currently in force in the country.

The SUS has as principles, respect for human rights and citizenship and an organized base of data that guides and facilitates actions, giving priority to comprehensive care and preventive activities. The ultimate goal is to make people's access to health services faster and more organized, unified throughout the national territory, and above all, functional. His philosophical doctrinal principles are universality, comprehensiveness and equity. The private sector acts as a complementary assistance, allowing the population access to specialized services not yet available in the public health network.

Therefore, the aforementioned initiatives now are public health in Brazil, although still far from meeting all the complexity and demands of the population. For example, Goulart and Carvalho (1998) opine that the system of decentralization needs to be deeper, strengthening the mechanisms that regulate the transfer of resources, which is still a means to maintain centralized decision-making process, imposing the standardization of policy alternatives. These authors argue that it would be essential that the Ministry of Health attributed greater importance to the evaluation of results and provides compensatory measures to state and municipal systems based on health indicators and quality of care.

In short, the health sector is a mutant system in constant construction that accompanies social change and, as such, needs assessments and updates according to the social demands, economic and technological policies. These assessments need to involve all parties concerned, including doctors and other health professionals, important actors in this process. The multidetermination of health conditions requires, as a counterpart, a multi-sectoral action and the 
commitment of governments in order to ensure health to the population. The face of today's challenges is the construction of alternatives for tomorrow, involving the commitment and responsibility of governments to society, and respect to their needs and diversity. Following, the health and professional working environment in this area is considered, particularly doctors.

\section{The Health Professionals' Health as Object of Study}

Health and disease are closely related to the conditions in which people live and work. job categories, groups and social classes, do not get sick and die from the same causes as they do not live and work in the same conditions. As provided by the Law 8080/90, which regulates the conditions for the promotion, protection and recovery of health, this has the determinant and conditioning factors, among others, food, housing, sanitation, environment, work , income, education, transport, leisure and access to essential goods and services (Diário Oficial da União, 1990).

The classic definition of health, presented by the World Health Organization (WHO), is that health is a state of complete physical, mental and social well-being, cannot be understood merely as the absence of disease (WHO, 1960). It is a definition that gives a positive concept of health, a state susceptible to graduations, it admits the possibility of having more or less health without necessarily being sick.

This definition suggests that the physical, mental as well as the social well-being demand, for obtaining and / or maintaining, a performance of various sectors of the organized society. For example, it includes, in addition to activities in the health field, those of public policies in the educational field, social security, employment, promotion and income. These are usually carried out under the control and responsibility of the State. Therefore, it is relevant to study the health professionals involved in their maintenance, especially when part of a not limited to the physical-organic dimension concept of health to include other aspects such as the sociocultural context. In this sense, we recognize the people involved, as well as biological aspects, the interdependence between subjectivity and its dynamics with the social and economic environment in which they live and work. An environment in which there is a clear lack of 
resources, leading these professionals to perform their duties in very different context of the ideal postulated by the current system of health care.

In this study, concern for health professionals is based on the need to produce knowledge that can serve as a basis for the implementation of policies that enable an improvement in their working conditions and, consequently, the quality of health promotion for the population. According to Vasconcelos (1995), conducting evaluation studies in health is extremely useful, enabling the improvement of the services provided in order to meet both the expectations of users and service providers to provide relevant information on which to base the planning of decisions to be taken with regard to improving the management of health services.

The interest in discussing the welfare of doctors, in this way, is due to the fact that currently the quality of health services offered to the population has been the subject of waged daily discussions not only by health professionals from around the country but also by the users of services and managers in general. Thus it is perceived a tendency in Brazil in search of the quality of public health services. As resources for the sector become increasingly scarce and, on the other hand, social inequalities increase, the need for care and attention intensify, making it a real challenge to produce quality healthcare (Gil Silva, fields \& Baduy, 2001).

It is known that quality requires a new mindset, both users and health institutions, regarding the rights of the individual to autonomy, to quality care and health. In this context, an assessment of the health professionals involved in the process becomes important when considering that the real improvement in health care necessarily involves the care of the needs for improvement of working conditions of its employees.

Although there is consensus on the need to make assessments in order to generate health services with more quality, assessments have been a challenge for researchers. In addition to the technical and methodological difficulties (eg, lack of well-defined criteria, lack or shortage of financial resources, lack of professional training) and political-institutional (eg neglect at the organizational difficulties, authoritarian character of studies highlighting differences individual), there is still resistance from the professionals themselves towards change in their current practices.

Social psychology can contribute to the theme in that it deepens the look in the subjective dimension related to health practices and the experiences of workers in the sector, constantly updating the relationship between health, the conditions of life and work, among 
other things, even the social context in which such practices develop. This area has given emphasis in the search for meanings present in the culture to explain various phenomena of human nature (Bruner, 1997; Fiske, 1992). According to Bruner (1997), the meanings are mediator components of the relationship between the individuals and theirs world. In this way, says this author, a culturally sensitive psychology is and should be based not only on what people actually do, but in what they say they do and what they say that led them to do what they did. It also relates to what people say others have done and why. And, above all, it refers to what people say that are their worlds.

Saying and doing therefore constitute the meanings constructed by the individual and are causes of their actions. Thus, knowing the meanings that health workers attribute to their work can help to build a scientific basis for the choice of strategies for change aiming at improving the conditions of the work itself, so that it is perceived by the employee as appropriate to professional practice. In the case of doctors and other health professionals, their positive interaction with the work environment is essential, so that it is a rewarding and fulfilling experience. In this respect, the environment and the realization of the service conditions play an important role in determining the quality of the relationship of the person with his work, which will lead directly to his/her well-being.

According to Maslach and Leiter (1999), it is the structure and functioning of the workplace that are likely to determine the way people perform their work activities. If there is no human activity recognition, professional wear risk increases, resulting in impairment of both the work and workers' mental health. Therefore, work is fundamental to the psychological, biological and social development of human beings; It is an important means of relationship and communication with society.

It is presumed there is a close relationship between the working environment and health status, as described Soriano (1983): "tell me where you work and I will tell you that how you will get ill" (p. 45). Objectively, the immediate risks of the job are usually accidents and illnesses to which workers are exposed due to the unhealthy environment, the characteristics of materials and tools that are used, as well as the various "environmental" factors as conditions of temperature, ventilation, noise, contact with chemical or bacteriological agents (Forastieri et. al., 1983). However, other factors of more subjective nature, but no less harmful to workers' health, also taking place in the employment context, 
tending to cause or predispose to the formers; among these dissatisfaction, psychological discomfort and stress can be cited (Borges et. al., 2005).

In summary, it seems clear that a key step in the care and health prevention is the recognition of the possibility of an existing disease due to the declared presence of suffering, especially among those who are caregivers by profession. Of course only the identification of such factors alone does not relieve suffering, but brings the possibility of becoming aware of the risks they are exposed as professionals and contribute to reflect on preventive and curative measures for them. The following is an overview of the work of doctors and the recent changes in their labor practice.

\section{The Meaning of Work and the Medical Profession}

Initially, one must understand the work as an essential human activity; it is a process of interaction between man and nature in such a man, with his intentional action, measures, regulates and controls your metabolism with nature. By working through this movement, he sought to modify it and, in doing so, changes his own nature. Thus it is the intention that distinguishes human work from the one done by other animals. The existence of conscience and freedom is what makes it unique, not being moved only for survival that guides most species (Garcia, 1984).

Garcia (1984) presents a human working model consisting of two dimensions: an abstract or quantitative, in which there is human labor expenditure in the physiological sense. In this case, human labor would be compared to a commodity; the other dimension is referred to as concrete or qualitative, where the human workforce in appropriate form, would be destined to an end, and this quality of concrete work would produce use value. The useful work, creator of use value, is an incentive to develop the physical and mental capacities of the human being, becoming understood as a source of satisfaction and pleasure. Thus, these dimensions of human labor should be thought as inseparable.

Under capitalism's point of view, the abstract work would be appropriated by the capitalist to remunerate the employee, looking for that it could recover physical energy consumed in its execution. It is here compared to a commodity. The work in this sense becomes an object of exchange, and the capitalist production system removes the meaning of 
work to the worker, generating alienation of labor (Garcia, 1984). Therefore, alienation is the decoupling of activity and subject imposed by the capitalist mode of production. The producer no longer identifies the product of his work, this becomes an object. It is objectified. The worker begins to identify its activity as strange, not belonging to him. The working practice is the transformation of one object into another by means of human labor expenditure, with the use of certain means and instruments. Therefore, It has three basic components: object, means or instruments of work and activity or work itself (Paim, 1992; Schraiber, 1992). The medical work of the object constitutes the human body in its anatomic, physiological and psychological composition. This body, however, is not simply a mass of cells, tissues or biochemical reactions; it is a human body, living in society, it is invested of value.

For the realization of their work, there must be a set of means that the worker intervenes directly between him and his object of work, to carry out the work itself. In the case of medicine, such means may be either instruments which produce the desired processing (e.g., a scalpel, forceps, needles, medicaments) and other more subjective (e.g., knowledge of the pathology, clinical reasoning, the identification of tests). There are still those who do not participate directly in the process, such as the workplace and interpersonal dynamics among employees, but are fundamental to professional practice (Paim, 1992; Schraiber, 1992). Therefore the work itself is characterized as human energy (physical and emotional) used in the production process. In the case of medical work, physical and intellectual expenditure puts such a professional in the category of intellectual worker, which could result in a perception and awareness of responsibility that predisposes to stress.

To start a reflection on the medical work, it is necessary to know a little about the contextual changes that come through this profession (but the changes are not restricted to this profession). Some authors refer to considerable changes in work organization in recent years as a result of the sharp scientific and technological development. Thus, the organization of human labor has experienced a model of control and regulation called Scientific Labor Organization (OCT), which adopted a scientific methodology to replace empirical labor regulation methods (Schraiber., 1991; Schraiber \& cols, 1994).

This period is identified by several authors as the consolidation and development of a particular form of work organization, and specifically the medical work. This form of organization constitutes a step in the development of capitalism by imposing an organization 
new standard characterized by mass production and consumption. This new work organization model imposed the employee a strict control system and performance evaluation, based on individual and collective productivity standards, not always taking into account individual differences and peculiarities of each professional category. Its main features are based (1) on the concentration of resources in the same organization; (2) on the separation between intellectual work (work of those who plan) and physical work (work of those performing), which are the control and supervision of the activities carried out by planners; (3) on the encouragement to the division of knowledge and practices in organizations, stimulating specialization; (4) on the division of the organization in sectors with common goals and single command; and (5) on the adequacy of the worker for the work performed, ensuring greater efficiency and productivity (see Schraiber, 1991; Schraiber et al, 1994).

This new form of work organization implies both in practice and in the development of medicine, which no longer adopt the handmade model of individualized control of their workforce, assuming this new model to rationalize the work. In this sense, we adopt the following guidelines as paradigms (Schraiber, 1993; Mendes, 1986): the mechanism (the human body is seen as similar to a machine); the biologicism (reduces man to his biological components); individualism (focuses on the biochemical and physiological aspects, to the detriment of psychological, social and cultural); the specialization (promotes fragmentation of knowledge and practices in medicine); the exclusion alternative practices (limited therapeutic practice legally instituted actions); the concentration of health workforce (promotes the concentration of workforce and equipment in the same environment, in this case the hospital); the technification of the medical act (using expensive and sophisticated technologies to carry out its actions); and finally, the emphasis on curative medicine (focuses attention on the disease and not health).

Being able to apply the capitalist logic to the health system model, it has also become possible to manage those who produce, in this case, doctors. In particular, the hospital turns into a space for possible implementation of this new medical work organization model (Federal Council of Medicine, 1998; Schraiber, 1993; Mendes, 1986). This new logic of medical work and its replanning consequently allowed a predominance of scientific and technological dimension of medicine, which began to direct current work processes, imposing a new standard of academic training, especially valuing the technology and expertise as 
mechanisms of acquisition of scientific knowledge and integration into the labor market (Mendes, 1986; Novaes, 1990).

These changes in work organization in Brazil begin to significantly impact from the second half of the twentieth century, when the installation of US companies that implement and disseminate this model of work organization. At the same period, the Brazilian social security system also consolidated itself, ensuring medical and pharmaceutical assistance to workers formally regulated by the Consolidation of Labor Laws (CLT). The workers' access to social benefits, among them health care, decreased the strength of the workers' struggle for improvement of working conditions (Mendes, 1986; Novaes, 1990). By the 1970s, due to significant losses of productivity in the economy, especially in the United States, to intensify labor struggles for better pay. In response to these demands, the prices of goods and services rose, generating a growing inflationary wave (Druck, 1999; Schraiber Medici \& Gonçalves, 1994).

Investment in new technologies that would generate increased productivity led to the evolution of robotics, informatics and communications, producing profound changes and fostering unemployment. The amortization of the new crisis at work appears through benefits offered by the state of social welfare, materialized on unemployment benefits or social assistance programs. Again capitalism retains its standard management and organization of work and society, by which established itself as a form of social protection (Druck, 1999).

By that time also Japanese companies began to propose and broadcast internationally labor organization standards based on quality. Thus, the quality and differentiation of products have become essential as a base for competitiveness. The use of modern technology, robotics and computing in the new work organization model impacted once again in the labor society. Because of these changes and the need for investments in technological modernization, the capacity of the state for social investment runs out, making it impossible for their actions of amortization of the social crisis generated by new forms of work organization, international technology and competition. As a result, an increase in unemployment was inevitable, which led workers to move their demands for salary increases and for maintaining employment (Druck, 1999; Schraiber et al, 1994). According Druck (1999), in the 1990s, as a result of previous years of crisis and due to the weakening of workers' claims, the state reduces its implementation of actions of social policy, which 
exacerbates unemployment and social exclusion of employees, who can only be incorporated into the productive system through precarious forms of employment.

The new form of work organization based on the Japanese model, generated a very hierarchical and differentiated system among companies of different sizes, as follows: in the case of large companies, these offered greater opportunities for job stability, invested in skilled labor, had fixed compensation and/or variable in accordance with the increase in production. The organization of work was based on the culture of total quality, which presupposed the participation of workers involved in the search process for productivity and cost reduction. For small and medium-sized enterprises, these tended to form a network of subcontracting, where there were all kinds of work. In general, they were unstable and hired the labor of its workers precariously. These tended to have low professional qualifications and to submit to poor working conditions, low wages and strict control to achieve the required quality and productivity standards (Druck, 1999).

As one of the consequences for medicine, these changes have made its professionals begin to suffer from the reduction in pay, extension of working hours, poor signings, control and supervision of their activities, loss of professional autonomy, among other changes, that have reduced the prestige of this category in society. Regarding the fragmentation of knowledge through market demand for specialization has led to adverse effects, as the high specialization of medicine involves the use of new technologies, which in turn burdens and prevents the costs to the end consumer (the customer) away from the doctors. On the other hand, the customer can no longer accept the most basic procedures, such as history analysis and auscultation, by sheer insecurity or distrust in the process. In addition, the race for specialization tends to alienate the young doctors of basic areas and lead to loss of social credibility of these professionals (Goulart \& Carvalho, 1998).

The abusive use of technological resources tends to provoke a professional dependence on these resources, thus leading to a gradual loss of clinical reasoning skills. Complementary tests have become technical protection instruments and cool for a good portion of medical professionals (Goulart \& Carvalho, 1998). So specialize became the solution, not only to preserve the technical autonomy, but mainly to maintain the credibility and social prestige. Deeply understand only part of the medical scientific knowledge ends up being for the professional area, a safer attitude, a better practice to capitalist reality, in a world increasingly globalized, individualized, competitive and legalistic. 
It is important to recognize that the way medical work is organized in society imposes on medical education their own laws and functioning. Such teaching just reinforced this situation to some extent, because the medical education has a certain autonomy, which leads to the generation of contradictions with the demands encountered in medical practice. If medical practice requires specialization as a way of entering the labor market, it influences the training school and the medical school curriculum, which generally adapt to that situation. However, within the limits imposed by reality, there can be creativity and innovation. Incidentally, it should be recognized a relative autonomy of the medical school to propose new models of professional practice, working in conflict and dialectically and thus being able to perform real transformations.

In short, adopting the materialistic view of the determination of the economic structure over the other components of society lead to the changes occurring in capitalist society and, as a consequence of these, the ones observed in medical work. From a handmade model, more autonomous, to a model dominated by loss of autonomy with wage and dependence on technology. These transformations in the medical work organization and new forms of insertion of the doctor in the labor market point to difficulties that the category is facing today (Carneiro \& Gouveia, 2004). This is best handled in the following topic.

\section{The doctor and his Working Context}

The vision of medicine and medical role that prevails in societies is built into realities that change dynamically as you adjust to changes in social contexts. According to Machado (1997), the economic structure determines the place and manner of articulation of medicine and doctors as a professional category in the social structure. So think of the doctor's work is also thinking about the circumstances in which the relationship between the professional and his work are established with different contextual structures.

Medicine is a science that aims, among other things, maintenance and restoration of health. In a broader sense, seeks solutions to the prevention and cure of diseases (physical and psychological) that affect humans. It is the area of operation for professionals formed in a medical school (WHO, 2001). 
For a better understanding of this science, a brief historical overview follows. The word "medicine" derives from the Latin ars medicina, means "the art of healing," and refers to a series of practices, approaches and knowledge, techniques and exercises that, combined, tend to enable the restoration of an organism, prevent diseases and maintain welfare (WHO, 2003). According to information from the World Health Organization (Who, 2003), the history of medicine dates from 460-377 BC with Hippocrates, who favored this science with an ethical, moral and scientific achievements on details of the disease, use of medicinal plants, teas, infusions, clisters, among other practices valid today.

In the first century of the Christian era, Galen, another Greek physician, gave substantial contributions (based on animal violations) for the development of medicine. In the middle ages, the church begins to play an important role especially in infectious diseases. It was only in 1965 that Louiz Pasteur made his great contribution about infections and how to prevent them through the pasteurization process. In 1928, Alexander Fleming discovered penicillin and medicine enters a new era in terms of preventing and curing diseases.

In Brazil, one of the oldest institutions was the National Academy of Medicine, founded in 1829 by Dr. Souza Meireles under the name of Medical Society. The official teaching of medicine began in November 1808, when by decree of King John VI, the Anatomic-Surgical and Medical School was established in the city of Salvador, Bahia, today medical school UFBA and later pioneered the National School of Medicine. In Brazil, the medical profession is regulated in Resolution issued by the Federal Council of Medicine (CFM).

Clinicians historically have always possessed respectability and high social prestige, arising from the direct relationship with patients and probably due to the form of individual and autonomous work; a doctor-patient relationship based on trust, respect and professional secrecy. The health care itself was once an artisan craft, which was gradually turning into a capitalist production system, where medical work has become a socially valued commodity. Doctors were subjected to the rules of this new way to exercise their craft, developing its activities in public and private services. Consequently, they were subject to the rules imposed on other workers in any capitalist enterprise, as job instability (when he had opportunity to have some), intense pace of work, long working hours, wage, together with the medical work of the special features, such as ease pain and suffering, and have death as a routine situation (Machado, 1997; Nics, 1998; Pitta, 1990). 
In a pioneering research conducted in Brazil, in São Paulo, Donnangelo (1999) has pointed to the wage of doctors, although associated with other forms of integration in the labor market. Machado (1996), in a study on the profile of physicians in Brazil, noted a disturbing reality about these professionals: $80.4 \%$ indicate feeling worn in their activities, accumulating several jobs with long hours, getting to meet from 12 to daily 14 hours. It found that such professionals then living a process of wage and loss of autonomy at work, and over half of these physicians perceived the future of the profession with pessimism and uncertainty. Other studies have also sought to portray the main characteristics of these professionals and their labor market, such as (Machado, 1997; Ministry of Health, 1998):

- The medical labor market has about 350,000 jobs in the public and private sectors, for a quota in the mid-1990s to 183,052 doctors nationwide. It was observed that $74.7 \%$ of these professionals also have activities in private practices, which implies a real market of at least 500,000 jobs. This is equivalent to 2.7 jobs or activities by a physician.

- In all regions of Brazil the professional activity was predominantly carried out in hospitals in both the public and private sectors.

- In the case of private clinics, $79.1 \%$ of doctors working with covenants and / or health cooperatives, and $16.6 \%$ of them exercised this activity within health facilities.

- $65.9 \%$ of physicians worked in state capitals, particularly in the social and economically developed. This concentration contributed to a ratio of 3.28 doctors per thousand inhabitants in the capital, more than six times that observed in inner cities $(0.53$ doctor per thousand inhabitants).

- Only ten medical specialties, among the 65 recognized by the time, excel in the medical services market, which covered $62.1 \%$ of total Brazilian doctors.

- Approximately half of these professionals, that is, $48.9 \%$ worked in shifts, with greater frequency shifts of 12 and / or 24 hours.

At the time there is also evidence about the increasing specialization, reduction in pay, multiplicity of employments, increasing participation of women in the medical profession, high achievement of shifts between forms of work and the growing informalisation of labor relations. These results show that the labor market for physicians in Brazil has played the general trend of the contemporary economy of operation and flexibility of hiring workforce (Machado, 2000). 
A more recent study shows even more alarming data (Carneiro \& Gouveia, 2004). In this study, about $52 \%$ of doctors on duty exercised activities, mode of tiring and exhausting work, especially when it is developed in environments with lack of adequate equipment and materials, endangering the health of those who want help. Also the remuneration of these professionals once again been short of your expectations. The study showed that $72 \%$ of them had individual monthly income of less than US \$3,000.00 (three thousand dollars), when they revealed that they would be satisfied with a monthly income of US $\$ 4,000.00$ (four thousand dollars). Note, the wage gap. This, together with other precarious conditions in the exercise of the medical profession, committed to life satisfaction of these professionals. This potentially makes their work, which should be a source of pleasure, a source of displeasure, feelings of meaninglessness, worthlessness and helplessness, potentially devastating stressors to health and subjective well-being.

Machado (1997) noted that the number of medical professionals increases 3.8\% more than the population, which has its growth rate around $1.8 \%$ per year. Thus, a relatively large number of medical professionals entered the labor market each year, generating high competitiveness by excess labor force, increasing need for training, fair remuneration problems and decreased status and professional prestige, conflict generators. In this sense, it is not surprising that in recent decades the working conditions have deteriorated, with a dissatisfaction with the remuneration received as a result of medical work. These professionals feel tired, unmotivated and apathetic toward life; medical activity has ceased to be a source of desire and pleasure to become a source of wear due to the bureaucracy of exhaustive working hours, the quantity of inquiries, acts and required therapeutic procedures (Carneiro \& Gouveia, 2004; Machado, 1996).

In nationwide surveys conducted in 1995 (Machado, 1996) and 2003 (Carneiro \& Gouveia, 2004), seeking to map out the main characteristics of physicians and their work context, stood out increasing participation of women in the category, concentration of professionals in the urban centers, especially in large cities, intense pace of work, long working hours, predominance of duty activities, especially among younger doctors, work overload and dissatisfaction with the profession.

The Regional Medicine Council of São Paulo conducted a study on the medical labor market in São Paulo. On that occasion, it was observed that a significant share of physicians had accumulation of working hours, which amounted to three or more activities, such as wage 
labor, autonomous practice in offices and work in hospitals. In the public sector, predominated hiring doctors employed form and in the private sector, providing services through cooperatives or medical companies. This form of contracting was considered as a market trend, especially in private hospitals (CREMESP, 2002).

In short, the day-to-day exhausting, often without adequate rest, sleeping badly and feeding poorly, working hard and earning little, just in contrast to the need to address the social representations that this professional category have. Thus, the doctor needs to have a beautiful office, wear stylish clothes and have a modern car to identify themselves as belonging to a social elite. This preliminary framework points elements needed to understand how recent changes in the medical work impact not only on the quality of their work production, but also has implications damaging their own health, among these the labor exhaustion and psychological discomfort.

\section{References}

Borges, L. O. (2005). Os profissionais de saúde e seu trabalho. São Paulo: Casa do Psicólogo.

Bruner, J. (1970). Actos de significado: Para uma psicologia cultural. Tradução Vanda Prazeres. Lisboa: Edições 70.

Carneiro, M. B. \& Gouveia, V. V. (2004). O médico e o seu trabalho: Aspectos metodológicos e resultados do Brasil. Brasília: Conselho Federal de Medicina.

Carvalho, A. I. (1995). Conselhos de Saúde no Brasil: Participação cidadã e controle social. Rio de Janeiro: Fase/IBAM.

Conselho Regional De Medicina Do Estado de São Paulo (2002). Mercado de Trabalho Médico no Estado de São Paulo. São Paulo: CREMESP.

Dâmaso, R. ( 1995). Saber e práxis na reforma sanitária - Avaliação da prática científica no movimento sanitário. Em S. F. Teixeira (Org.), Reforma sanitária: em busca de uma teoria (pp. 61-90). São Paulo: Cortez. Rio de janeiro, 1995.

Diário Oficial da União (1990). . Lei 8080, de 19 de setembro de 1990 que Dispõe sobre as condições para a promoção, proteção e recuperação da saúde, a organização $e$ o funcionamento dos serviços correspondentes, e dá outras providências. Recuperado em 18 de Janeiro de 2008 de http://www.planalto.gov.br/ccivil/leis/L8080.htm, 1990. 
Donnângelo, M. C. F. (1999). Medicina e sociedade - o médico e o seu mercado de trabalho. São Paulo: Pioneira.

Druck, M. G. (1999). Terceirização: (des)fordizando a fábrica. Salvador, BA: EDUFBA.

Fiske, S. (1992). Thinking is for doing: portraits of social cognition from daguerreotype to laserphoto. Journal of Personality and Social Psychology, 63, 877-889.

Gil, C. R. R., Silva, A. M. R., Campos, J. J. B. \& Baduy, R. S. (2001). Avaliação em saúde.Em S. M., Andrade, D. A., Soares \& C. L. Júnior (Orgs.), Bases da saúde coletiva (p.125-132). Londrina: UEL.

Goulart, F. A. A. \& Carvalho, G. C. M. (1998). Os médicos e a saúde no Brasil.Brasília: Conselho Federal de Medicina.

Luz, M. T. (1994). As conferências nacionais de saúde e as políticas de saúde na década de 80. Em R. Guimarães \& R. Tavares (Org.), Saúde e sociedade no Brasil (p. 131-152). Rio de Janeiro: Relume-Dumará.

Machado, M. H.(1997). Os médicos no Brasil: Um retrato da realidade. Rio de Janeiro: Fiocruz.

Maslach, C. \& Leiter, M. (1999). Trabalho: Fonte de prazer ou desgaste. Campinas, SP: Papirus.

Mendes, E. V. (1986). A evolução histórica da prática médica. Suas implicações no ensino, na pesquisa e na tecnologia médica. Belo Horizonte, MG: PUC-MG/FINEP.

Mendes, E. V. (1995). As políticas de saúde no Brasil nos anos 80: a conformação da reforma sanitária e a construção da hegemonia do projeto neoliberal. Em E. V. Mendes (Ed.), Distrito sanitário: O processo social de mudança das práticas sanitárias do Sistema Único de Saúde (p. 19-92). São Paulo: Hucitec-Abrasco.

Nics, L. F. (1998). Managed care. Médicos HC/FAMUSP, 1(2), 97-105.

Novaes, H. M. (1998). Ações integradas de saúde nos Sistemas Locais de Saúde - SILOS. São Paulo: PROAHSA.

Organizacion Mundial De La Salud.(1960). Documentos básicos. Genebra: OMS.

Paim, J. S. \& Almeida Filho, N. Saúde coletiva: uma "nova saúde pública”ou campo aberto de problemas? Revista de Saúde Pública, 32, 299-316, 1998.

Pitta, A. (1990). Hospital, dor e morte como ofício. São Paulo: Hucitec.

Pouvourville, G. (1999). Public health research: between science and action?Cadernos de Saúde Pública, 15, 889-894. 
Rosen, G.(1994). Uma história da saúde pública. São Paulo: Hucitec/ABRASCO.

Schraiber, L. B.(1991). Profesión médica representación, trabajo y cambio. Educación Médica y Salud, 25, 58-71.

Schraiber, L. B. (1992). O trabalho médico e a clínica na medicina moderna. São Paulo: Centro de Formação dos Trabalhadores da Saúde.

Schraiber, L. B. (1993). O médico e o seu trabalho: Limites da liberdade. São Paulo: HUCITEC.

Schraiber, L. B., Medici, A. C. \& Gonçalves, R. B. (1994). El reto de la educación médica frente a los nuevos paradigmas económicos e tecnológicos. Educación Médica y Salud, 28, $20-52$.

Soriano, J. B. (1995). Satisfação e sentido: uma análise do trabalho do professor de educação física. Em Universidade Estadual de São Paulo (Org.), Anais do Simpósio de Educação Física da UNESP (p. 45-88). Rio Claro, SP: UNESP.

Vasconcellos, M. P. C. (1995). Memórias da saúde pública: A fotografia como testemunha. São Paulo: Hucitec,.

World Health Organization, (2002). Men, ageing and health. Disponível em: . Acesso em 02/03/2008.

World Health Organization (2003). Fact sheet $N^{\circ} 134$ : Traditional medicine.Disponível em: . Revisado em Maio/2003. Acesso em 02/03/2008.

Received: 12/10/2016.

Accepted: 14/10/2016

\section{How to cite this article (APA format):}

Oliveira, Sidney M. \& Nascimento, Vânia B. (2016). Life and Work Health Professionals. Am Int Mul J, 1(1),38-58. 